\title{
9th International Congress on Twin Studies Helsinki, 4-6 June 1998
}

The 9th International Congress on Twin Studies has been held for the first time in Scandinavia. This triennial congress is the main event under the aegis of the International Society for Twin Studies. Local organisers were the Finnish Twin Cohort Study, Department of Public Health, University of Helsinki, and the Finnish Association of Multiple Birth Families. The congress was held at the university lecture halls of the medical faculty of the University of Hel sinki, close to the centre of Helsinki.

The three-day congress was composed of plenary sessions (in the mornings) and parallel sessions (in the afternoons) with posters on view for the duration of the congress. There were over 200 participants from 19 countries. A total of 150 abstracts were submitted, with about half being presented orally, the other half as posters. There was a wide range of topics on all aspects of multiple births.

The congress opened on Thursday 4 June 1998 with a plenary lecture by Leena Peltonen (Helsinki) on Genes in Finland, which gave an overview of the current research into monogenic and complex diseases in Finland, and some of the unique aspects of Finland. The plenary symposium on Design and analysis of twin studies was organised by Dorret Boomsma and Mike Neale, providing an overview of current developments in methodology.

The afternoon symposia were Asthma and allergy, chaired by Lauri Laitinen (Helsinki), Health-related behaviour and well-being for the whole of life (Jennifer Harris, Oslo), Behaviour in childhood and adolescence (Seija Sandberg, Jyväskylä), Chronic disease and aging (Pia Verkasalo, Helsinki) and Issues in the management of multiple pregnancies (Håkan Ryhdström, Lund). After a long day, the congress delegates relaxed at the City of Helsinki evening reception with good food and drink to the sound of classical music provided by a Finnish ensemble, and piano music played by the Uvarov twins from St Petersburg conservatory.

Friday started with an exciting plenary lecture by Nick Martin (Brisbane) on what we know and do not yet know about the genetics of twinning. The plenary symposium chaired by Kaare Christensen (Odense) and Markku Koskenvuo (Turku) dealt with the very topical issue of the relationships between Foetal programming, cardiovascular disease and twins. David Phillips (Southampton) gave an overview of the argument for foetal programming in chronic disease, which was followed up by the papers on epidemiological and molecular genetics.

During the lunch break, the ISTS business meeting was held and a new Board of Directors was elected. The main event of the Society over the last two years was the launching of its own journal Twin Research.

In the afternoon the parallel symposia were Why are MZ twins different? (chair, Nick Martin), Psychosocial aspects of multiple births (Elizabeth Bryan, London), Genetics and biology of twinning (Aldur Eriksson, Helsinki) and Anthropometric measures and developmental rates (Walter Nance, Richmond). The day closed with the congress banquet at the Sea Fortress of Suomenlinna just outside Hel sinki, preceded by a tour of the city's main sights and an overview of its history.

On the final day of the congress, the plenary lecture was give by Lea Pulkkinen (Jyväskylä), who placed many developmental twin studies in context by an overview of The transition from adolescence to adulthood. The plenary symposium chaired by Irma Moilanen (Oulu) and Pat Preedy (Durham) was on Abnormal and normal development in childhood and adolescence.

Afternoon parallel symposia 'Twin studies of substance abuse: transitions across time, gender, and culture' chaired by Dick Rose (Bloomington, Indiana) and Sleep disorders and other neurological diseases (Markku Partinen, Helsinki) closed the congress.

In parallel with the scientific sessions, the Council of Multiple Birth Organizations (COMBO) held several meetings to organise and set an agenda for its activities. During Saturday afternoon and evening, many delegates attended the annual meeting of the Finnish Association of Multiple Birth Families, held in conjunction with the congress.

A detailed programme and list of abstracts can be found at the ISTS website: http://kate.pc.helsinki.fi/ twin/ists.html. Support for the congress was given 
by the Medical Research Council, Academy of Finland, the City of Helsinki and the University of Helsinki. I should like to thank all the people who contributed their time and effort to making the congress possible. I should al so like to thank all the congress participants for coming to Helsinki and making the congress a success.

Jaakko Kaprio Congress Organizer 